A N N A L E S

UNIVER S T ATIS M A R A E C URIE-SKŁODOW K A

LUBLIN - POLONIA

VOL. XXXII, 3

SECTIO J

2019

Państwowa Wyższa Szkoła Zawodowa w Koszalinie. Instytut Spraw Społecznych

\title{
RENATA LEMAŃCZYK
}

ORCID: 0000-0003-4077-3131

renlem@wp.pl

\section{Psychoprofilaktyka zachowań ryzykownych u młodzieży}

Psycho-prevention of Risky Behaviour among Youths

\section{STRESZCZENIE}

W niniejszym artykule została ukazana specyfika zachowań ryzykownych wśród młodzieży oraz działań psychoprofilaktycznych, z którymi wiąże się niebezpieczeństwo negatywnych konsekwencji zarówno dla nich samych, jak i dla ich otoczenia. Przedstawiony model psychoprofilaktyki jest ukierunkowany na przygotowanie do życia i radzenie sobie z codziennymi problemami, wartości i autorytety oraz wypracowanie poczucia odpowiedzialności u młodych ludzi za ich działania i umiejętność rozróżniania dobra od zła. Niniejszy artykuł jest nie tylko teoretycznym wskaźnikiem, lecz także wskazówką do prowadzenia działań mających na celu minimalizację zachowań ryzykownych wśród młodych ludzi.

Słowa kluczowe: profilaktyka zachowań ryzykownych; strategie psychoprofilaktyki; program profilaktyki

\section{WPROWADZENIE}

Niepokojące statystyki z ostatnich lat dotyczące picia przez młodzież alkoholu, zażywania środków psychoaktywnych, zachowań agresywnych czy przestępczych, agresji skierowanej na siebie, nadużywania internetu, cyberprzemocy, aktywności seksualnej, pornografii internetowej, gier komputerowych propagujących przemoc, niszczenia własnej kariery szkolnej czy zaburzeń odżywiania skłaniają do podejmowania prób poszukiwania przez badaczy i praktyków pracujących z młodzieżą rozwiązań ograniczających rozmiary tych zachowań ryzykownych. Aby móc za nimi podążać, należy więcej umieć, rozumieć, a przede 
wszystkim sprawniej i skuteczniej działać. Strategie, z którymi jednocześnie wiąże się wzrost zainteresowania działaniami psychoprofilaktycznymi, ukierunkowanymi zwłaszcza na młodych ludzi, mają zatem w niniejszym artykule swoje uzasadnienie.

\section{CHARAKTERYSTYKA ZACHOWAŃ RYZYKOWNYCH U MŁODZIEŻY}

Zachowania ryzykowne, zwane też często zachowaniami problemowymi, można określić najogólniej jako różne działania niosące ryzyko negatywnych konsekwencji zarówno dla zdrowia fizycznego i psychicznego jednostki, jak i dla jej otoczenia społecznego (Szymańska, 2012; Ostaszewski, 2014). Zachowania ryzykowne wywołuje najczęściej określona sytuacja życiowa, która powoduje, że młody człowiek nie jest w stanie jej sprostać. Największe nasilenie zachowań ryzykownych przypada na okres adolescencji, który wiąże się z większym prawdopodobieństwem wystąpienia problemów ze zdrowiem, utrudnień w relacjach społecznych oraz szkód rozwojowych (Dzielska, Kowalewska, 2014).

W literaturze wyróżnia się cztery powiązane ze sobą rodzaje ryzykownych zachowań wśród młodzieży (Ostaszewski, 2014; Woynarowska, 2017, s. 439):

- klasyczne zachowania problemowe (np. picie alkoholu, używanie środków psychoaktywnych, przedwczesne kontakty seksualne, zachowania antyspołeczne),

- zachowania antyzdrowotne, które nie powodują sankcji społecznych, ale prowadzą do negatywnych skutków dla zdrowia (np. „niezdrowy” sposób odżywiania, zachowania sedenteryjne, mała aktywność fizyczna),

- nieodpowiednie wypełnianie roli ucznia, wyróżnione ze względu na znaczne ryzyko dla prawidłowego rozwoju (np. złe oceny, wagary, przerwanie edukacji),

- $\quad$ tzw. nowe zachowania ryzykowne, określane także jako problemy lub uzależnienia behawioralne (np. hazard, cyberprzemoc, siecioholizm).

Podejmowanie zachowań ryzykownych przez młodych ludzi jest często mechanizmem radzenia sobie $w$ trudnych sytuacjach życiowych, takich jak niepowodzenia w nauce czy konflikty w kontaktach $\mathrm{z}$ chłopakiem lub dziewczyną. Większa skłonność do podejmowania zachowań ryzykownych występuje więc u młodych ludzi, gdyż są narażeni na negatywne wpływy rówieśników i konfliktowe relacje rodzinne. Popularnymi sposobami wyjścia z owej sytuacji są często: ucieczka w zachowania problemowe, zwiększona skłonność do eksperymentowania, poszukiwania nowych doświadczeń i testowania swojej niezależności (Ostaszewski, 2014, s. 343; Ostaszewski, 2017).

Wielu autorów wskazuje zgodnie, że zachowania ryzykowne chodzą parami lub często idą w parze z innymi problemami, mają tendencję do współwystępowania np. z problemami w szkole (Gaś, 2000; Szafraniec, 2011; Ostaszewski, 2017; Woynarowska, 2017). Jeżeli więc z jakichś względów jedno zachowanie jest utrudnione lub niemożliwe, to młody człowiek może wbudować $\mathrm{w}$ to miejsce $\mathrm{z}$ koniecz- 
ności inne negatywne zachowanie. Oznacza to, że inicjacja jednego zachowania ryzykownego znacząco zwiększa prawdopodobieństwo wejścia w następne zachowania ryzykowne, np. picie alkoholu czy odurzanie się narkotykami toruje najczęściej drogę inicjacji agresji i przestępczości, palenie tytoniu ułatwia przekraczanie następnych barier, a tym samym przyspiesza i toruje drogę inicjacji alkoholowej. Pod wpływem alkoholu młodzi ludzie podejmują wiele innych zachowań ryzykownych, np. dopuszczają się agresji skierowanej na ludzi bądź przedmioty. Również część inicjacji seksualnych dokonuje się pod wpływem alkoholu (Szymańska, 2012). Wiele zachowań ryzykownych podejmowanych przez młodzież związanych jest też z gwałtownym rozwojem technologii informacyjnych (Pyżalski, 2012).

Zachowania ryzykowne młodzieży są w dużym stopniu przemijającym epizodem, związanym ze specyficznymi potrzebami i zadaniami okresu adolescencji. W drodze do dorosłości młodzież musi nauczyć się samodzielności oraz ukształtować swoją osobowość i tożsamość.

\section{PRZYCZYNY I KONSEKWENCJE ZACHOWAŃ RYZYKOWNYCH U MŁODZIEŻY}

Koncepcję wyjaśnienia zachowań ryzykownych zaproponowali Richard i Shirley Jessor. Zgodnie z ich teorią zachowania ryzykowne mają m.in. znaczenie rozwojowe i umożliwiają młodemu człowiekowi (Szymańska, 2012):

- zaspokojenie najważniejszych potrzeb psychologicznych (takich jak: miłość, akceptacja, uznanie, bezpieczeństwo, przynależność) oraz potrzeb emocjonalnych (radzenie sobie z przeżywanymi trudnościami życiowymi, redukcja lęku i frustracji),

- realizację ważnych celów rozwojowych (np. określenie własnej tożsamości, poszukiwanie wartości, uzyskanie niezależności od dorosłych).

Młody człowiek, który nie znajduje akceptacji, miłości bądź nie ma poczucia przynależności społecznej w środowisku swego życia, może poszukiwać swego miejsca, podejmując określone zachowanie ryzykowne (np. sięgać po alkohol, zacząć „,́́pać” itp.), kierując się przy tym różnymi motywami. Przyczyn takich zachowań należy szukać prawdopodobnie w sferze psychospołecznego funkcjonowania jednostki i na tej płaszczyźnie można jedynie przeciwdziałać temu zjawisku. Palenie np. jest traktowane jako źródło przyjemności, a papieros staje się atrybutem dorosłości oraz służy nawiązywaniu kontaktów społecznych, poza tym pozwala upodobnić się do ludzi odnoszących sukcesy, bohaterów filmów i reklam (bogatych, młodych, pięknych, zdrowych, szczęśliwych). Wystarczy zapalić papierosa tej samej marki, by poczuć się jednym z nich (Pstrąg, 2000, s. 62-63). Perspektywa niepalenia i dożycia późnej starości nie jest więc dla młodzieży zbyt atrakcyjna. Nie odmówią sobie „tak wielkiej przyjemności” tylko po to, by zostać w dalekiej przyszłości tym, kim nie chcą być, tj. starcami. 
Wśród najczęściej występujących motywów zachowań ryzykownych wymienia się (Szymańska, 2012; Dzielska, 2017):

- motywy ucieczkowe: ucieczka od problemów rodzinnych i szkolnych, ucieczka od pustki, nudy i monotonii, ucieczka od samotności i lęku - charakterystyczne wśród młodzieży $\mathrm{z}$ wysokim poziomem tendencji autodestrukcyjnych, która próbuje albo zwrócić uwagę na siebie i swoje problemy, albo rzeczywiście pragnie pozbawić się życia,

- motywy konformizmu: upodabnianie się do innych członków grupy rówieśniczej, aby uzyskać ich uznanie, oparcie, przyjaźń,

- motywy egzystencjalne: poczucie sensu życia, pustka wewnętrzna,

- motywy poszukiwania: ciekawość jak działa narkotyk, chęć przeżycia czegoś niezwykłego,

- motywy hedonistyczne: dążenie do przyjemności, zmniejszenie zahamowań,

- motywy prestiżowe i snobistyczne: chęć pokazania się bardziej dorosłym, zaprezentowania się jako osoby ważnej, ciekawej, wyróżniającej się ponad przeciętność.

Wspólnym mianownikiem różnych zachowań ryzykownych podejmowanych przez młodzież są niewątpliwie negatywne konsekwencje zdrowotne i rozwojowe. Zachowania te według wielu badaczy mogą (Ostaszewski, 2014; Woynarowska, 2017):

- stwarzać zagrożenie dla zdrowia i bezpieczeństwa oraz wiązać się z częstym występowaniem problemów zdrowotnych i wypadków,

- utrudniać młodym ludziom prawidłowe funkcjonowanie w rolach społecznych właściwych dla ich wieku, w tym: utrudniać wypełnianie roli ucznia, narażać na konflikty z prawem, prowadzić do okresowej izolacji lub wykluczenia społecznego, przyczyniać się do przedwczesnego rodzicielstwa i wielu problemów z tym związanych,

- zakłócać rozwój osobisty, kształtowanie się tożsamości i adekwatnego obrazu samego siebie, co sprzyja powstawaniu takich problemów psychicznych, jak zaburzenia nastroju, depresyjność, myśli i próby samobójcze,

- utrudniać nabywanie umiejętności potrzebnych w dorosłym życiu, zdobycie odpowiedniego wykształcenia i umiejętności zawodowych, co przekłada się na problemy z zatrudnieniem i utrudniony start $\mathrm{w}$ dorosłe życie.

Motywy podejmowanych zachowań ryzykownych przez młodzież są zatem podobne lub nawet identyczne. Często młody człowiek wybiera jakieś konkretne zachowanie, ponieważ jest ono najprostszym sposobem w realizacji bądź pozwala na osiągnięcie ważnego dla niego celu. Może to być spowodowane chęcią uzyskania aprobaty grupy społecznej lub najbliższych członków rodziny. Nie zdaje sobie jednak sprawy z konsekwencji wyboru danego zachowania (tabela 1). 
Tabela 1. Przykłady informacji o bezpośrednich zdrowotnych i psychospołecznych negatywnych skutkach wybranych zachowań ryzykownych

\begin{tabular}{|c|c|}
\hline Zachowanie & Przykłady informacji o negatywnych skutkach \\
\hline $\begin{array}{l}\text { Picie } \\
\text { alkoholu }\end{array}$ & $\begin{array}{l}\text { - konflikty z rówieśnikami (bójki), rodzicami (,,szlabany” w domu), } \\
\text { nauczycielami w szkole (pogorszenie ocen) } \\
\text { - } \text { konsekwencje pogorszonej koordynacji wzrokowo-ruchowej oraz oceny } \\
\text { sytuacji: wypadki i urazy, utrata kontroli nad swoim ciałem } \\
\text { - konsekwencje utraty świadomości z powodu wypicia dużej ilości alkoholu: } \\
\text { zamarznięcia, kradzieże, wykorzystywanie seksualne, zakrztuszenie się } \\
\text { wymiocinami } \\
\text { - podejmowanie ryzykownych decyzji pod wpływem alkoholu: ryzykowne } \\
\text { kontakty seksualne, wykroczenia, inne wysoce ryzykowne zachowania grożące } \\
\text { utratą życia, np. jazda z pijanym kierowcą, zabawy na dachu lub balkonie na } \\
\text { dużej wysokości, eksperymentowanie z dopalaczami, narkotykami, lekami } \\
\text { - konsekwencje prawne wybryków i zachowań antyspołecznych } \\
\text { podejmowanych pod wpływem alkoholu: zawiadomienie szkoły, rodziców, } \\
\text { skierowanie sprawy do sądu rodzinnego, nadzór kuratora }\end{array}$ \\
\hline $\begin{array}{c}\text { Palenie } \\
\text { papierosów }\end{array}$ & $\begin{array}{l}\text { - konsekwencje estetyczne: brzydki zapach ubrań i własnych pomieszczeń, } \\
\text { palenie papierosów w ukryciu, np. w toaletach } \\
\text { - konsekwencje związane z relacjami społecznymi: konflikty z rodzicami, } \\
\text { problemy w relacjach intymnych z niepalącym partnerem/partnerką, trudności } \\
\text { w znalezieniu zatrudnienia } \\
\text { - konsekwencje ekonomiczne: wydawanie znacznej części kieszonkowego na } \\
\text { papierosy, zmniejszenie swojej „,siły nabywczej” } \\
\text { - konsekwencje zdrowotne: gorsza wydolność organizmu i kondycja fizyczna, } \\
\text { większa podatność na infekcje, uzależnienie }\end{array}$ \\
\hline $\begin{array}{l}\text { Nadużywanie } \\
\text { internetu }\end{array}$ & $\begin{array}{l}\text { - konsekwencje zdrowotne wielogodzinnego przesiadywania przed monitorem } \\
\text { komputera: zwiększona podatność na infekcje, pogorszenie nastroju lub } \\
\text { nasilenie problemów zdrowia psychicznego, bóle w okolicy szyi, ramion, } \\
\text { nadgarstków, zaburzenia neurologiczne, trudności w zasypianiu } \\
\text { - konsekwencje społeczne: osłabienie kontaktów osobistych z innymi ludźmi, } \\
\text { poczucie izolacji i osamotnienia, zaniedbywanie bezpośrednich relacji } \\
\text { z bliskimi } \\
\text { - zaniedbywanie obowiązków w szkole i w domu, konflikty z rodzicami } \\
\text { - utrata lub osłabienie dotychczasowych zainteresowań i zajęć, np. zaprzestanie } \\
\text { uprawiania sportu, niepodejmowanie wysiłku fizycznego, aktywności } \\
\text { towarzyskich, nieczytanie książek }\end{array}$ \\
\hline $\begin{array}{l}\text { Uprawianie } \\
\text { hazardu }\end{array}$ & $\begin{array}{l}\text { - konsekwencje finansowe: utrata kontroli nad pieniędzmi (gracz wydaje więcej } \\
\text { pieniędzy na grę, niż chce lub planował, pożycza pieniądze) } \\
\text { - konsekwencje dla życia rodzinnego: kradzieże domowe (gracz kradnie lub } \\
\text { wydaje pieniądze z budżetu domowego i przeznacza je na granie, kłamie na } \\
\text { temat swojego grania lub utrzymuje swoje uzależnienie w tajemnicy przed } \\
\text { bliskimi) } \\
\text { - konsekwencje dla swoich zainteresowań: hazard staje się najważniejszą rzeczą } \\
\text { w życiu, gracz zaczyna wierzyć w „wielką wygraną” i obsesyjnie do niej dąży } \\
\text { - konsekwencje dla zdrowia psychicznego: gracz zaczyna uprawiać hazard, aby } \\
\text { uciec od problemów życiowych i trudnych emocji }\end{array}$ \\
\hline
\end{tabular}

Źródło: (Woynarowska, 2017, s. 443). 
Nie można zaprzeczyć, że podejmowane przez młodzież zachowania stanowią sygnał dla dorosłych i należy je traktować poważnie. Jeśli ten sygnał zostanie dostrzeżony we wczesnym etapie podejmowania przez nich zachowań ryzykownych, to umiejętna pomoc nauczyciela, rodzica czy terapeuty może koncentrować się na bezpośrednich zdrowotnych i psychospołecznych skutkach zachowań ryzykownych, a tym samym może przyczynić się do rozwiązania zaistniałego problemu oraz pozwolić na wycofanie się z zachowań ryzykownych.

\section{PODEJMOWANIE ZACHOWAŃ RYZYKOWNYCH PRZEZ MLODZIEŻ - STATYSTYKA}

Wyniki wielu badań wskazują, że tylko część młodzieży - od kilkunastu do trzydziestu kilku procent - przechodzi przez okres adolescencji bez zaangażowania się w zachowania o dużym ryzyku dla zdrowia i rozwoju. Większość młodzieży należy albo do grupy umiarkowanego ryzyka (eksperymentatorów), czyli podejmuje kilka zachowań ryzykownych, albo do grupy dużego ryzyka (około 25\% młodzieży), w której występuje wiele takich zachowań (Woynarowska, 2017, s. 440). Należą do nich: palenie tytoniu, picie alkoholu, upijanie się, używanie innych substancji psychoaktywnych, bójki, wczesna inicjacja seksualna, zjawisko przemocy rówieśniczej w środowisku szkolnym, dręczenie i przemoc rówieśnicza. Choć wiedza o tych zachowaniach ryzykownych jest znacząca, ponieważ znane są ich etiologiczne i fenomenologiczne aspekty oraz skutki, a także powszechne są informacje z zakresu czynników chroniących i czynników ryzyka, to jednak wyniki wielu badań prowadzonych w Polsce (m.in. międzynarodowe badania ankietowe nad zachowaniami zdrowotnymi młodzieży szkolnej HBSC, badania ESPAD oraz „badania mokotowskie”) świadczą o tym, że rozmiary podejmowania tych zachowań przez młodzież są duże i podlegają dynamice, stąd konieczność ich ciągłego monitorowania (Gołembowska, 2017, s. 8).

Wyniki badań HBSC przeprowadzonych w 2014 r. wskazują (Mazur, 2015), że:

1. W grupie 11-15-latków:

- $12 \%$ paliło papierosy z różną częstością, $8 \%$ paliło regularnie,

- $\quad 43 \%$ piło alkohol z różną częstotliwością, $6 \%$ co najmniej raz w tygodniu,

- $21 \%$ upiło się co najmniej raz w życiu, a 3\% ponad 10 razy,

- $31 \% \mathrm{w}$ ostatnim roku brało udział w bójkach z rówieśnikami,

- $\quad 31 \%$ było w ostatnich dwóch miesiącach co najmniej raz sprawcami dręczenia rówieśników.

2. W grupie 15-16-latków:

- $24 \%$ używało marihuany lub haszyszu co najmniej raz w życiu,

- $\quad 17,5 \%$ przeszło inicjację seksualną.

Wyniki badań nad rozpowszechnianiem nowych zachowań ryzykownych wśród młodzieży pozwalają stwierdzić, że w sposób ryzykowny: 
- około 5\% uprawia gry hazardowe (Niewiadomska i in., 2015),

- około 16\% korzysta z internetu i komputera (Pisarska, Ostaszewski, Raduj, Wójcik, 2014).

Wyniki badań ankietowych przeprowadzonych w 2015 r. wśród młodzieży w ramach międzynarodowego projektu „European School Survey Project on Alcohol and Drugs" (ESPAD) ukazują natężenie zjawiska zachowań ryzykownych wśród młodzieży (Sierosławski, 2015):

1. Najbardziej rozpowszechnioną substancją psychoaktywną wśród młodzieży są napoje alkoholowe:

- 83,8\% uczniów z młodszej grupy (15-16-latków) oraz 95,8\% uczniów ze starszej grupy (17-18-latków) chociaż raz w ciągu całego swojego życia piło,

- 48,6\% 15-16-latków i 82,3\% 17-18-latków piło w czasie ostatnich 30 dni,

- najbardziej popularnym napojem alkoholowym wśród młodzieży jest piwo, a najmniej - wino.

2. Palenie tytoniu jest zachowaniem mniej powszechnym:

- 56,2\% uczniów z młodszej grupy i 71,5\% uczniów ze starszej grupy chociaż raz w życiu paliło,

- 26,4\% 15-16-latków i 41,7\% 17-18-latków paliło w czasie ostatnich 30 dni.

3. Używanie substancji nielegalnych wśród uczniów:

- $25 \%$ uczniów z młodszej grupy i 43\% uczniów ze starszej grupy chociaż raz w ciągu całego życia używało substancji nielegalnych,

- wśród 15-16-latków pod względem rozpowszechniania używania substancji nielegalnych jest LSD lub inne halucynogeny,

- wśród 17-18-latków dominuje amfetamina, marihuana i haszysz.

4. Rozpowszechnianie używania tzw. dopalaczy:

- 10,3\% 15-16-latków oraz 12,6\% 17-18-latków sięgnęło po „dopalacze” w czasie ostatnich 30 dni.

5. Zagrożenia wynikające $\mathrm{z}$ gier hazardowych:

- 8,5\% 15-16-latków oraz 10,8\% 17-18-latków deklaruje takie zachowanie.

Jak pokazują wyniki dotychczasowych badań ogólnopolskich, picie alkoholu przez młodzież stało się niemal statystyczną normą. Używanie substancji nielegalnych, rozpowszechnianie „dopalaczy” i nadużywanie internetu to coraz bardziej widoczne problemy młodzieży. Niewątpliwie konieczne jest podejmowanie w tym zakresie nie tylko badań na poziomie regionalnym i lokalnym, lecz także konkretnych działań profilaktycznych, również w skali kraju.

\section{POZIOMY PSYCHOPROFILAKTYKI}

Psychoprofilaktykę zachowań ryzykownych najtrafniej można określić jako proces wspomagania człowieka w radzeniu sobie z zachowaniami problemowymi, które zagrażają zarówno jego prawidłowemu rozwojowi, jak i życiu, a także 
ograniczenie i likwidowanie czynników, które zaburzają ten prawidłowy proces oraz dezorganizują zdrowe życie (Gaś, 2002). W takim rozumieniu jest ona systemem działań na określonych poziomach, których celem jest zapobieganie wystąpieniu lub rozpowszechnieniu się różnych odmian wykolejenia społecznego, a jednocześnie ukształtowanie $u$ jednostki pozytywnych cech osobowych.

Psychoprofilaktyka w związku z tym powinna być prowadzona na trzech poziomach (Gaś, 2002; Szymańska, 2012; Gaś, Poleszak, 2017):

1. Profilaktyka pierwszorzędowa - adresowana do grup niskiego ryzyka. Działania są podejmowane, zanim problemy się pojawią lub przekształcą się w sytuację kryzysową. Działaniami prewencyjnymi obejmuje się szerokie i niepoddane diagnozie populacje. Realizatorami programów są przede wszystkim nauczyciele wspierani przez specjalistów. Głównym terenem działań jest szkoła. Profilaktyka pierwszorzędowa ma dwa cele: promocję zdrowego stylu życia oraz opóźnienie wieku inicjacji, a przez to zmniejszenie zasięgu zachowań ryzykownych. Poprzez różne działania przekazuje się młodzieży następujący komunikat: „Poczekaj do dorosłości!”.

2. Profilaktyka drugorzędowa - adresowana do grupy podwyższonego ryzyka. Działania są podejmowane we wstępnej fazie rozwoju trudności. Ukierunkowane są na jednostkę lub grupę, a ich celem jest rozwiązanie zaistniałego problemu i odzyskanie przez nastolatka poziomu konstruktywnej funkcjonalności oraz zabezpieczenie go przed poważniejszymi trudnościami. Cele i zadania profilaktyki drugorzędowej sprowadzają się do diagnozy i ograniczenia głębokości i czasu trwania zachowań ryzykownych. Obejmują:

- edukację specyficznych populacji i jednostek traktowanych jako grupy (osoby) wysokiego ryzyka,

- redukcję występowania problemów eksperymentalnie lub okazjonalnie oraz zachowań ryzykownych w sytuacjach wysokiego ryzyka,

- redukcję zjawiska piętnowania osób o zachowaniach ryzykownych i propagowanie zdrowego stylu życia.

Realizatorami programów są głównie psychologowie, socjoterapeuci, doradcy rodzinni (przy czym ważne jest też wsparcie psychologów klinicystów). Zajęcia prowadzone są najczęściej w poradniach psychologiczno-pedagogicznych, placówkach oświatowo-wychowawczych i socjoterapeutycznych. Działania obejmują swoim zakresem strategie wczesnej identyfikacji, wczesnej diagnozy i interwencji oraz techniki interwencji kryzysowej. Przez różne działania przekazuje się komunikat: „Wycofaj się!”.

3. Profilaktyka trzeciorzędowa - adresowana do grupy wysokiego ryzyka. Działania są podejmowane po rozwiązaniu kryzysu i koncentrują się na osobach, które poradziły sobie z kryzysem. Profilaktyka ta ma na celu przeciwdziałanie pogłębianiu się procesu chorobowego i degradacji społecznej oraz umożliwienie powrotu do normalnego życia w społeczeństwie. Głównie są to leczenie, rehabilitacja i resocjalizacja. 
W profilaktyce trzeciorzędowej realizatorami programów są lekarze specjaliści, psychologowie klinicyści, psychoterapeuci, rehabilitanci, pracownicy socjalni, kryminolodzy, wyspecjalizowani pracownicy policji itp. Programy te wymagają współpracy między przedstawicielami wielu resortów. Terenem tych działań są poradnie specjalistyczne, szpitale, zakłady karne, placówki wychowawcze i resocjalizacyjne.

Wskazuje się na następujące cele profilaktyki trzeciorzędowej (Gaś, 2002, s. 20-21):

- zatrzymanie rozwoju zachowań ryzykownych,

- redukcję niebezpieczeństwa powrotu do zachowań ryzykownych,

- usprawnianie formy pomocy dla osób o zachowaniach ryzykownych i ich rodzin,

- poprawę jakości życia rodzin z osobą problemową,

- redukowanie zachowań ryzykownych współwystępujących z innymi zachowaniami ryzykownymi,

- likwidowanie piętna społecznego, jakie ciąży na osobach przejawiających zachowania ryzykowne.

Wynika z tego, że bardzo ważne w psychoprofilaktyce jest zachowanie kolejności działań. Im głębszy jest poziom profilaktyki, tym większe są koszty związane z koniecznością zatrudniania wysoko wykwalifikowanych specjalistów, dłuższy czas trwania terapii oraz mniejsza skuteczność. Na każdym poziomie działania profilaktyczne zakładają inne cele, angażują różne zadania oraz formy realizacji działań i śledzenia skutków (Wojcieszek, 2002; Kawula, 2003, s. 425). Nie ulega wątpliwości, że działania profilaktyczne powinny być tak zaplanowane i prowadzone, aby ewentualny opór czy trudności nie zatrzymały wartościowych zadań oraz by ograniczanie szkód wynikających z przejawianych zachowań umożliwiło nastolatkom wycofanie się z zachowań ryzykownych.

\section{STRATEGIE PSYCHOPROFILAKTYKI I ICH SKUTECZNOŚĆ}

Niebezpieczne skutki zachowań ryzykownych można w znacznym stopniu ograniczyć przez odpowiednią edukację i działania profilaktyczne. Strategie profilaktyczne mają na celu redukowanie lub kompensowanie czynników ryzyka przez rozwijanie wiedzy, przekonań i umiejętności chroniących młodych ludzi przed angażowaniem się w zachowania ryzykowne. Odpowiednio dobrane i przekazane informacje mogą im pomóc w osiągnięciu ważnych dla nich celów oraz w realizacji potrzeb rozwojowych. Niezbędne jest więc edukowanie i uwrażliwianie młodych ludzi na zagrożenia związane z podejmowaniem niepotrzebnego ryzyka (Ostaszewski, 2014; Woynarowska, 2017, s. 441).

W profilaktyce zachowań ryzykownych wymienia się kilka strategii (Szymańska, 2012): 
1. Strategie informacyjne - dostarczenie informacji na temat skutków zachowań ryzykownych i tym samym umożliwienie dokonywania racjonalnego wyboru. U podstaw tej strategii leży przekonanie, że młodzi ludzie zachowują się ryzykownie, ponieważ zbyt mało wiedzą o mechanizmach i następstwach takich zachowań. Zakłada się, że dostarczenie informacji o skutkach zachowań ryzykownych (wykład, film) spowoduje u nich zmianę postaw oraz w rezultacie wpłynie na zmianę zachowań.

Programy informacyjne muszą spełniać wiele warunków, aby rzeczywiście miały znaczenie zapobiegawcze. W przypadku zaniechania przestrzegania pewnych zasad działania mogą one mieć bardzo niską skuteczność lub nawet spowodować poważne szkody. Ogromne znaczenie ma również osoba przekazująca wiadomości. Od jej wiarygodności w znacznym stopniu zależy siła oddziaływania informacji. W związku $\mathrm{z}$ tym stawia się działaniom informacyjnym następujące warunki:

- przekazywane informacje powinny być dostosowane do możliwości percepcyjnych odbiorcy i już posiadanego zasobu wiedzy,

- przekazywane informacje powinny być rzetelne i podawane rzeczowo, aby nie wzbudzać ciekawości lub niedowierzania,

- przekazywane informacje nie powinny być zbyt szczegółowe, aby nie stanowiły instruktażu dla konkretnego zachowania ryzykownego.

2. Strategie edukacyjne - celem jest pomoc w rozwijaniu ważnych umiejętności psychologicznych i społecznych (umiejętności nawiązywania kontaktów z ludźmi, radzenia sobie ze stresem, rozwiązywania konfliktów, opierania się naciskom otoczenia itp.). U podstaw tych strategii leży przekonanie, że nawet ludzie dysponujący odpowiednią wiedzą podejmują zachowania ryzykowne wynikające z braku wielu umiejętności niezbędnych w życiu społecznym. Deficyt w zakresie kompetencji społecznych uniemożliwia im budowanie głębszych, satysfakcjonujących związków z ludźmi, powoduje ciągłą frustrację, uniemożliwia odnoszenie sukcesów (np. zawodowych). Szukają więc chemicznych podpórek, by przetrwać. Programy edukacyjne składają się z bloków ćwiczeń, w których uczestnicy mogą poznawać własne braki w zakresie różnych umiejętności i zacząć je trenować. Są to przeważnie ćwiczenia właściwego komunikowania się, mówienia „nie” w sytuacji nacisku grupowego, odraczania reakcji emocjonalnych, relaksacji itp.

Strategie edukacyjne skupiające się na kształtowaniu i rozwijaniu umiejętności psychologicznych i społecznych uważane są za jedne z najbardziej skutecznych. Trening w zakresie kształtowania tych umiejętności powinien stanowić ważny element szkolnych programów profilaktycznych, których celem jest redukcja zachowań ryzykownych.

3. Strategie alternatyw - celem jest pomoc w zaspokojeniu ważnych potrzeb (np. sukcesu, przynależności) oraz osiągnięciu satysfakcji życiowej przez stwarzanie możliwości zaangażowania się w działalność pozytywną (artystyczną, spo- 
łeczną, sportową itp.). U podstaw tych strategii znajduje się założenie, że wielu ludzi nie ma możliwości zrealizowania swej potrzeby aktywności, podniesienia samooceny poprzez osiąganie sukcesów czy też rozwoju zainteresowań. Dotyczy to zwłaszcza dzieci i młodzieży zaniedbanej wychowawczo. Motywem jest tutaj tzw. nuda, a „dzieci ulicy” są tego najlepszym przykładem. Działania profilaktyczne polegają właśnie na stwarzaniu alternatyw dla zachowań ryzykownych (coś zamiast picia, ćpania czy agresji). Są to miejsca oferujące atrakcyjne zajęcia: kluby sportowe, koła zainteresowań, teatry amatorskie albo zespoły muzyczne, harcerstwo itp. Strategie alternatyw są dość powszechnie oceniane jako skuteczne, choć trudno w badaniach ocenić ich efektywność, ponieważ efekty mogą się pojawić po dłuższym czasie. Programy alternatyw organizowane w szkołach, na osiedlach czy w gminach stwarzają młodzieży możliwość zaangażowania się w działalność, która daje satysfakcję, sprzyja rozwojowi, która jest akceptowana społecznie i zapobiega angażowaniu się w działania destrukcyjne.

4. Strategie interwencyjne - celem jest pomoc osobom mającym trudności w identyfikowaniu się i rozwiązywaniu swoich problemów oraz wspieranie w sytuacjach kryzysowych. Trudno ocenić ich skuteczność. Realizowane programy wczesnej interwencji wymagają znacznej indywidualizacji podejścia. Wymienia się dwa warunki ich skuteczności: profesjonalizm i odpowiednie cechy osobowości osoby udzielającej pomocy (wiarygodność i zaufanie) oraz pozyskanie i włączenie rodziców ze względu na fakt powiązania zachowań ryzykownych z procesami zachodzącymi w rodzinie. Efektywność działań znacznie podnoszą treningi umiejętności wychowawczych dla rodziców, których dzieci przeżywają zaburzenia zachowania.

5. Strategie zmniejszania szkód (harm reduction) - przewidziane głównie na potrzeby profilaktyki trzeciorzędowej. Adresatami tych działań są grupy najwyższego ryzyka, w przypadku których zawiodły wczesna psychoprofilaktyka, interwencje, terapia, resocjalizacja. Są to narkomani i alkoholicy z długim stażem, prostytutki i recydywiści, którzy z różnych względów nie mogą lub nie chcą wycofać się z ryzykownych zachowań. Często żyją w trudno dostępnych gettach i stanowią niebezpieczny margines, wymykający się spod kontroli instytucji państwowych i społecznych.

Wymienia się następujące elementy strategii zmniejszania szkód: docieranie z opieką medyczną do narkomanów, wydawanie czystych narkotyków na receptę, wymianę igieł i strzykawek, leczenie substytucyjne (terapia metadonem), pomoc socjalną, dystrybucję prezerwatyw, promocję i dystrybucję innych środków sterowania płodnością.

Strategie zmniejszania szkód stosuje się nie tylko wobec osób z trudno dostępnego marginesu, lecz także wobec osób z krótkim stażem w zakresie zachowań problemowych (np. uprawianie prostytucji na własną rękę lub zatrudnianie się w agencjach towarzyskich). Uzasadnieniem tej strategii jest założenie, że wie- 
le osób nie zrezygnuje z zagrażających zachowań, należy więc zmniejszyć samo zagrożenie.

W literaturze odnajdujemy - wykorzystywane obecnie przez wielu praktyków - następujące strategie edukacji profilaktycznej (Ostaszewski, 2014; Woynarowska, 2017):

1. Strategia informacyjna - dostarcza się młodzieży odpowiednio dobrane informacje i koncentruje się na bezpośrednich zdrowotnych i psychospołecznych skutkach zachowań ryzykownych. Wykorzystuje się w nich nie tylko tzw. metody podające (pogadanki, wykłady, prelekcje, filmy, ulotki i inne materiały informacyjne), lecz również tzw. metody interaktywne (aktywna rola ucznia w procesie przyswajania informacji, wymiana myśli, dyskusja, zbieranie informacji i doświadczeń) oraz metodę projektów (dyskusja, wchodzenie w rolę, analizowanie i rozwiązywanie problemów).

Działania edukacyjne powinny skupić się na kształtowaniu subiektywnych norm i indywidualnych postaw, dwustronnej komunikacji nauczyciel-uczeń oraz otwartym stylu porozumiewania się uczestników i strategii słownej zwanej mową eksploracyjną.

2. Edukacja normatywna - kształtowanie i wzmacnianie subiektywnych norm przeciwnych podejmowaniu zachowań ryzykownych (na ile znaczące dla ucznia osoby akceptują planowane przezeń zachowanie lub go nie akceptują). Strategia edukacyjna polega na osłabianiu presji i korygowaniu błędnych przekonań młodzieży (subiektywnych norm) na temat rozmiarów i akceptacji używania substancji psychoaktywnych. Wykorzystuje się tutaj etapy uczenia się przez doświadczanie Davida Kolba.

3. Edukacja rówieśnicza - polega na modelowaniu właściwych postaw i zachowań prozdrowotnych, realizowanych wspólnie przez dorosłych i młodych liderów. Wykorzystuje się tutaj założenia teorii społecznego uczenia się (obserwację zachowań ludzi, naśladowanie). Edukację rówieśniczą prowadzą naturalni liderzy grup młodzieżowych lub znaczący rówieśnicy, wolontariusze. Typowymi zadaniami, które realizują liderzy, są np. kierowanie pracą zadaniową małych grup, prowadzenie dyskusji na forum grupy, odgrywanie scenek, prowadzenie zabaw edukacyjnych.

4. Psychoedukacja - celem jest wspieranie zdrowia psychicznego młodzieży, ich prawidłowego rozwoju, rozwijanie umiejętności psychospołecznych, które mogą im pomóc w nawiązaniu zdrowych relacji z rówieśnikami oraz radzeniu sobie z trudnymi emocjami i sytuacjami życiowymi, sprzyjają osiąganiu lepszych wyników w nauce i funkcjonowaniu w roli ucznia. Psychoedukacja w praktyce szkolnej polega na przekazywaniu wiedzy na temat wybranych umiejętności psychospołecznych i prowadzeniu ćwiczeń warsztatowych rozwijających te umiejętności (np. programy wychowawczo-profilaktyczne, szkoła promująca zdrowie). 
5. Edukacja w grupach ryzyka - odnosi się do młodzieży, która np. eksperymentuje z substancjami psychoaktywnymi, dokonała wykroczeń lub czynów chuligańskich, podejmuje ryzykowne zachowania seksualne, ma poważne kłopoty z wypełnianiem obowiązków szkolnych. Ten poziom działań jest określany jako profilaktyka selektywna i wskazująca. W pracy z uczniami przydatnym narzędziem jest metoda interwencji profilaktycznej w szkole. Jej celem jest powstrzymanie rozwoju zachowań ryzykownych, które najczęściej dotyczą używania substancji psychoaktywnych lub zachowań aspołecznych.

Wśród metod interwencji profilaktycznej wymienia się metodę dialogu motywującego (skoncentrowana na osobie, dyrektywna metoda wzmacniania wewnętrznej motywacji do zmiany przez badanie i przezwyciężanie ambiwalentnych uczuć i postaw) oraz minimalizowanie szkód (edukacja ukierunkowana na minimalizowanie lub ograniczenie szkód zdrowotnych i społecznych poprzez dostarczanie informacji, uczenie umiejętności i modyfikowanie postaw osób zachowujących się ryzykownie).

\section{PROGRAMY I DZIAŁANIA PSYCHOPROFILAKTYCZNE W ŚRODOWISKU SZKOLNYM}

Miejscem szczególnie intensywnych działań psychoprofilaktycznych na rzecz młodzieży powinna być szkoła. Szkoła ujawnia lub wręcz wyzwala trudności młodzieży związane z przyjmowaniem odpowiedzialności za własne życie, jest miejscem intensywnego rozwoju w zakresie funkcjonowania interpersonalnego i społecznego w grupie rówieśniczej oraz konfrontacji autorytetów i kształtowania się poczucia własnej tożsamości nastolatka. Szkoła wypełnia też znaczną część aktywnego życia młodzieży, a z perspektywy rodziców - jest sposobem weryfikacji oczekiwań związanych z własnym dzieckiem.

Oddziaływania psychoprofilaktyczne dotyczące zachowań ryzykownych są przedmiotem wielu analiz i badań. Według autorów zawsze sprowadzają się one w środowisku szkolnym do (Dzielska, 2017, s. 9-10):

- profilaktyki uniwersalnej: działań podejmowanych jak najwcześniej w ramach promocji zdrowia prowadzonej przez rodziców, wychowawców i opiekunów, pedagogów szkolnych, psychologów, nauczycieli. Celem tych działań jest promowanie zdrowego stylu życia, kształcenie właściwych postaw prozdrowotnych oraz kształcenie umiejętności psychospołecznych niezbędnych młodym ludziom w procesie socjalizacji,

- profilaktyki selektywnej: działań polegających na ograniczaniu czynników ryzyka związanych ze środowiskiem rodzinnym i rówieśniczym, obalaniu fałszywych przekonań normatywnych dotyczących zachowań ryzykownych, kształtowaniu umiejętności niezbędnych w rozwoju emocjonalnym i społecznym młodzieży (realizatorami tych programów są psychoterapeuci, psy- 
chologowie, pracownicy świetlic socjoterapeutycznych, doradcy rodzinni). Celem tych działań jest zapobieganie, ograniczenie lub zaprzestanie podejmowania przez młodzież zachowań ryzykownych,

- profilaktyki wskazującej, skierowanej do osób, u których rozpoznano pierwsze objawy zaburzeń lub szczególnie zagrożonych rozwojem problemów wynikających z podejmowania zachowań ryzykownych dla zdrowia. Jej realizatorami są osoby przygotowane w zakresie pomocy psychologicznej lub terapeuci.

Działania profilaktyczne prowadzone w środowisku szkolnym, które obecnie są upowszechniane w Polsce, zaprezentowali Bühringer i Kuenzel-Boehmer. Wyróżnili oni (Zajączkowski, 2003, s. 13-14):

1. Model oświaty zdrowotnej - celem jest przekazywanie informacji o zachowaniach niekorzystnych i ich konsekwencjach dla człowieka i społeczeństwa. Model ten może przyjmować następujące formy: rzeczowy przekaz informacji o zachowaniach dewiacyjnych w formie prelekcji, pogadanek, filmów edukacyjnych, plakatów itp., a także o ich negatywnym wpływie na jednostkę i społeczeństwo, eksponowanie skutków zachowań ryzykownych (plakaty, filmy, zdjęcia, spotkania z osobami, które zetknęły się z zachowaniami ryzykownymi, np. prelekcje wygłaszane przez trzeźwych alkoholików).

2. Model edukacji humanistycznej - celem jest prawidłowy rozwój osobowości, a dotyczy to np. poczucia własnej wartości, umiejętności wyrażania uczuć, radzenia sobie ze stresem itp. W modelu tym poprzez takie formy, jak praca w małych grupach, zajęcia integracyjne, gry i zabawy dąży się do korekty, wzmocnienia i rozwinięcia wyżej wskazanych zmiennych osobowościowych.

3. Model edukacji społecznej - celem jest kształtowanie u jednostek umiejętności przeciwstawiania się presji społecznej skłaniającej do zachowań ryzykownych. Model ten obejmuje naukę mówienia „nie” (czyli asertywności) oraz rozpoznawanie wpływów zewnętrznych na proces podejmowania decyzji (reklama, mass media).

4. Model edukacji w zakresie umiejętności życiowych - celem jest kształtowanie umiejętności umożliwiających zaspokajanie potrzeb psychicznych bez uciekania się do zachowań ryzykownych. Sprzyja temu np. budowanie pozytywnego obrazu siebie, podejmowanie decyzji społecznie akceptowanych itp.

5. Model alternatywnych form - celem jest kształtowanie umiejętności aktywnego spędzania czasu wolnego w sposób konstruktywny, a nie destrukcyjny. Formami działań są wszelkie sposoby spędzania czasu wolnego w różnorodnych świetlicach, klubach, na wycieczkach.

6. Model promocji zdrowia - celem jest doprowadzenie do dobrego samopoczucia we wszystkich sferach życia indywidualnego i zbiorowego. Model ten obejmuje wszelkie programy propagujące zdrowy styl życia bez nikotyny, alkoholu i narkotyków. 
Nowoczesne programy profilaktyczne stawiają sobie za cel nie tylko wyposażenie ich odbiorców w rzetelną wiedzę, jednocześnie bowiem istotne jest kształtowanie ważnych umiejętności psychospołecznych, w tym głównie przekonań i systemu wartości u młodych ludzi. Wykorzystuje się do tego cykle spotkań warsztatowych z elementami treningu i aktywnych metod pracy z grupą.

Bardzo ważną rolę w odniesieniu do tego rodzaju programów szkolnych odgrywa psycholog lub pedagog szkolny. Zasadniczo można wymienić kilka jego podstawowych zadań. Są to (Gaś, 1995, 2011):

1. Selekcja i wdrażanie programu - od psychologa czy pedagoga powinien zależeć wybór najodpowiedniejszego programu i jego ewentualna adaptacja do warunków lokalnych, tak aby uczniowie otrzymali najbardziej potrzebną im pomoc.

2. Konsultowanie - psycholog czy pedagog szkolny jest konsultantem i pełni funkcję łącznika między wiedzą psychologiczną a potrzebami uczniów, nauczycieli i programem szkolnym.

3. Modelowanie - uczenie się przez obserwację jest jednym z najważniejszych sposobów nabywania przez ludzi nowych zachowań, dlatego psycholog lub pedagog szkolny musi mieć świadomość, iż dostarcza wzorców zachowań zarówno uczniom, jak i dorosłym pracownikom szkoły.

4. Poradnictwo dla rodziców - psycholog lub pedagog szkolny zapoznaje rodziców z realizowanymi programami profilaktycznymi, pracuje na rzecz usprawnienia komunikacji między rodzicami a dziećmi, a także włącza rodziców w programy pomocy dla młodzieży.

5. Ocenianie programów pomocy - ze względu na to, że psycholog lub pedagog szkolny zna program i potrzeby szkoły, lecz sam bezpośrednio nie realizuje programu, powinien również opisywać, badać i oceniać efekty realizowanych programów profilaktycznych.

Sytuacja młodych ludzi wymaga specjalnych oddziaływań edukacyjnych i profilaktycznych. Schemat postępowania interwencyjnego pedagoga lub psychologa szkolnego składa się z trzech elementów (Woynarowska, 2017, s. 448):

- rozmowa indywidualna z uczniem, w której pedagog lub psycholog szkolny wykorzystuje właściwe techniki komunikacyjne i odpowiednio dobrane informacje,

- rozmowa z rodzicami ucznia, która służy nawiązaniu z nimi kontaktu, udzieleniu im wsparcia i zachęceniu do współpracy ze szkołą,

- monitorowanie zachowań ucznia.

Oddziaływania psychoprofilaktyczne należy organizować przy uwzględnieniu stanu zagrożenia młodzieży danej szkoły, dostosowując je do indywidualnych potrzeb konkretnej placówki i każdego ucznia z grupy zwiększonego ryzyka (Wojcieszek, 2002; Szymańska, 2012; Woynarowska, 2017). Współcześnie odchodzi się od profilaktyki, której podstawą jest pokazywanie negatywnych konsekwencji podejmowania tych zachowań na rzecz profilaktyki pozytywnej, której celem jest 
wzmacnianie zasobów wewnętrznych (indywidualnych właściwości, umiejętności) oraz zasobów zewnętrznych (relacji rodzinnych, więzi ze szkołą, pozytywnych relacji rówieśniczych) wzmacniających młodzież (Dzielska, 2017, s. 8).

Przedmiotem psychoprofilaktyki może być każdy problem, w odniesieniu do którego odczuwamy potrzebę uprzedzającej interwencji oraz wobec którego można zastosować środki zaradcze. Nie ma bowiem skutecznej profilaktyki bez zdiagnozowania problemu, któremu mamy przeciwdziałać. Wszystkie działania podejmowane na gruncie profilaktyki muszą też uwzględniać wiek odbiorców i dobro człowieka. Od tych warunków niewątpliwie zależy skuteczność programów realizowanych w szkole.

\section{ZAKOŃCZENIE}

Współczesna młodzież jest zdezorientowana i zagubiona w obecnie panujących warunkach społecznych. Zachodzące przemiany powodują zachwianie się poczucia stabilności i bezpieczeństwa u młodych ludzi. Często młody człowiek wybiera jakieś konkretne zachowanie, ponieważ uznaje je za najlepszy sposób zrealizowania ważnego dla niego celu. Kierując się różnymi motywami, niejednokrotnie zaczyna przejawiać zachowanie ryzykowne. A jeżeli takie zachowanie wywołuje uznanie rówieśników, to młody człowiek z niską pozycją w grupie rówieśniczej może je wybrać celowo, aby poprawić swoją pozycję. Jeżeli natomiast ma liczne pretensje do swoich rodziców, a zarazem wie, że boją się oni narkotyków, może wybrać „branie” jako skuteczne narzędzie w porachunkach z rodziną.

Przedstawiona specyfika i wskazane rozmiary zachowań ryzykownych u młodzieży w kontekście teoretycznym wręcz wymuszają podejmowanie działań, które - jak podaje Zbigniew Gaś (2000) - w przypadku osób zdrowych pozwolą podtrzymać funkcjonalność, z kolei osobom z pierwszymi przejawami trudności pomogą zarówno obronić się przed rozwojem dysfunkcji, jak i powrócić do zdrowia, natomiast osobom z rozwiniętą patologią stworzą możliwości poddania się terapii oraz rehabilitacji.

Model przeciwdziałania zachowaniom ryzykownym w takim ujęciu powinien być ukierunkowany na:

- przygotowanie młodzieży do życia i radzenia sobie w nim,

- wartości i autorytety, do których młody człowiek mógłby dążyć,

- wypracowanie u młodych ludzi poczucia odpowiedzialności za własne czyny oraz umiejętności określenia ich w kategoriach dobra i zła.

Niniejszy artykuł ma charakter teoretyczno-diagnostyczny i stanowi przyczynek do podjęcia dalszych badań w tym zakresie o wymiarze empirycznym. Współczesna młodzież z pewnością potrzebuje działań psychoprofilaktycznych, co będzie tematem kolejnego opracowania. Profilaktyka zachowań problemowych stanowi duże wyzwanie dla osób zaangażowanych w proces wychowania 
młodego pokolenia. Nie można być obojętnym wobec przemian obyczajowych, jakie objęły młodzież, oraz towarzyszących tym przemianom niepokojących zjawisk i zagrożeń. Upowszechnianie działań profilaktycznych ujawnia ich bowiem coraz więcej. Należy przy tym uwzględnić kształtowanie zanikających wzorców tych zachowań wśród dorosłych. Mam nadzieję, że ta uwaga będzie nie tylko teoretycznym drogowskazem, lecz także działaniem ukierunkowanym na potrzeby współczesnej psychoprofilaktyki. A przekonanie, że można i trzeba działać zapobiegawczo, stanie się atrybutem współczesnych szkół i placówek opiekuńczo-wychowawczych.

\section{BIBLIOGRAFIA}

Dzielska, A. (2017). Zachowania ryzykowne. Warszawa: Instytut Matki i Dziecka.

Dzielska, A., Kowalewska, A. (2014). Zachowania ryzykowne młodzieży - współczesne podejście do problemu. Studia BAS, 2(38), 141-170.

Gaś Z. (1995). Pomoc psychologiczna młodzieży. Warszawa: WSiP.

Gaś, Z. (2000). Psychoprofilaktyka. Procedury konstruowania programów wczesnej interwencji. Lublin: Wydawnictwo UMCS.

Gaś, Z. (2002). Od wychowania do profilaktyki. Remedium, 12, 8-11.

Gaś, Z. (2011). Profesjonalna profilaktyka w szkole. Nowe wyzwania. Lublin: Innovatio Press.

Gaś, Z., Poleszak, W. (2017). Opracowujemy i ewaluujemy program wychowawczo-profilaktyczny szkoły. Warszawa: Ośrodek Rozwoju Edukacji.

Gołembowska, M. (2017). Adolescencja a zachowania ryzykowne. Bydgoszcz: Wydawnictwo UKW.

Kawula, S. (2003). Współczesne zagrożenia w rozwoju dzieci i młodzieży. W: S. Kawula (red.), Pedagogika społeczna (s. 385-437). Toruń: Wydawnictwo Adam Marszałek.

Mazur, J. (red.). (2015). Zdrowie i zachowania zdrowotne młodzieży szkolnej w Polsce na tle wybranych uwarunkowań socjodemograficznych. Wyniki badań HBSC 2014. Warszawa: Instytut Matki i Dziecka.

Niewiadomska, I., Chwaszcz, J., Augustynowicz, W., Palacz-Chrisidiss, A., Bartczuk, R., Wiechetek, M. (2015). Narzędzie do oceny ryzyka zaburzeń związanych z hazardem wśród młodzieży. Serwis Informacyjny Narkomania, 2(70), 21-26.

Ostaszewski, K. (2014). Zachowania ryzykowne młodzieży w perspektywie mechanizmów resilience. Warszawa: Instytut Psychiatrii i Neurologii.

Ostaszewski, K. (2017). Używanie substancji psychoaktywnych jako przejaw zachowań ryzykownych młodzieży szkolnej. Dziecko Krzywdzone. Teoria, Badania, Praktyka, 16(1), 133-145.

Pisarska, A., Ostaszewski, K., Raduj, J., Wójcik, M. (2014). Czynniki związane z hazardem, kompulsywnymi zakupami oraz nadużywaniem Internetu wśród młodzieży w wieku 12-19 lat. Raport z badań. Warszawa: Instytut Psychiatrii i Neurologii.

Pstrąg, D. (2000). Wybrane zagadnienia z problematyki uzależnień. Rzeszów: Wydawnictwo WSP.

Pyżalski, J. (2012). Agresja elektroniczna i cyberbullying jako nowe ryzykowne zachowania mtodzieży. Warszawa: Oficyna Wydawnicza Impuls. 
Sierosławski, J. (2015). Używanie alkoholu i narkotyków przez młodzież szkolnq. Raport z ogólnopolskich badań ankietowych zrealizowanych w 2015 roku. Europejski Program Badań Ankietowych w Szkołach ESPAD. Warszawa: Krajowe Biuro ds. Przeciwdziałania Narkomanii i Państwowa Agencja Rozwiązywania Problemów Alkoholowych.

Szafraniec, K. (2011). Młodzi 2011. Warszawa: Kancelaria Prezesa Rady Ministrów.

Szymańska, J. (2012). Programy profilaktyczne. Podstawy profesjonalnej psychoprofilaktyki. Warszawa: Ośrodek Rozwoju Edukacji.

Wojcieszek, K. (2002). Wygrać życie. Szkolny program profilaktyki. Kraków: Rubikon.

Woynarowska, B. (red.). (2017). Edukacja zdrowotna. Podstawy teoretyczne-metodyka-praktyka. Warszawa: PWN.

Zajączkowski, K. (2003). Profilaktyka zachowań dewiacyjnych dzieci i młodzieży. Toruń: Wydawnictwo Adam Marszałek.

\section{SUMMARY}

This article presents the specifics of risky behaviour among adolescents and psycho-preventive actions, which are associated with the danger of negative consequences both for themselves and for their environment. Presented model of psycho-prevention is oriented towards following aspects: preparing youth to living and coping with everyday problems, the values and authorities thanks to which young people function properly, working out the sense of responsibility in young people for their actions and the ability to distinguish between good and bad. This article should not only be a theoretical indicator, but also a guide to conduct actions aimed at minimizing risky behaviour among young people.

Keywords: risky behaviour prevention; strategy of psycho-prevention; program of crime prevention 